\title{
High Precision 182W Systematics IN EUROPEAN INTRAPLATE VOLCANIC ROCKS
}

\author{
M.JANSEN $^{1}$,J.TUSCH $^{1}$, C.MÜNKER ${ }^{1}$, A. BRAGAGNI ${ }^{2}$, R. \\ AvANZINELLI $^{2}$ \\ ${ }^{1}$ Institut für Geologie und Mineralogie, Universität zu Köln, \\ Germany (*correspondence: mike-jansen@gmx.net) \\ ${ }^{2}$ Dipartimento di Scienze della Terra, Università degli Studi \\ di Firenze, Italy
}

Over the last years, most studies that adressed anomalous ${ }^{182} \mathrm{~W}$ isotope systematics in Phanerozoic rocks focussed on the ${ }^{182} \mathrm{~W}$ isotope compositon of Ocean Island Basalts (OIB) [e.g., 1]. It has been proposed that different components from the deep mantle account for the heterogenous W compositions found for different islands and even distinct units of a single volcanic edifice [e.g., 1]. While previous studies have been limited to plumes rooted in Large Low Shear Velocity Provinces (LLSVPs) at the Core Mantle Boundary $(\mathrm{CMB})$, volcanic rocks originating from shallower mantle domains have been sparsely analyzed. Hence, it remains ambiguous, if anomalous ${ }^{182} \mathrm{~W}$ is restricted to the lower-mantle domains. Here we present the first extensive dataset on a series of samples from the Central European Volcanic Province (CEVP), including Massif Central (MC), the Eifel Volcanic Field (EVF), as well as the Italian Magmatic Provinces (IMP). In the absence of clear thermochemical piles, extending the mantle transition zone beneath the CEVP [e.g., 2] and the IMP [e.g., 3], volcanic rocks from both provinces display a vast geochemical and petrological variability with different mantle domains being involved. Consistently, all of our investigated samples from the CEVP do not display resolvable ${ }^{182} \mathrm{~W}$ anomalies, indicating no influence of an anomalous lower-mantle domain. In the case of the IMP, Mt. Etna's geochemical sigantures indicate an OIB affinity, despite its proximitiy to the Aeolian slab. Interestingly, the oldest samples from Mt. Etna and the associated Hyblean Plateau display resolvable ${ }^{182} \mathrm{~W}$ deficits as low as $\mu^{182} \mathrm{~W}=-7$. These deficits dissappear with increasing contributions from subduction components. Lacking seismic evidence for a lower-mantle connection, such deficits indicate that ${ }^{182} \mathrm{~W}$ anomlies might not be restrcited to deep rooted mantle plumes. In the case of Mt. Etna, the anomalous signatures can be best explained by the heterogenization of the upper mantle throughout the inflow of African asthenosphere [3].

[1] Mundl-Petermeier et al., (2019), Geochimica et Cosmochimica Acta 271, 194-211, [2] Ritter et al., (2001), Earth and Planetary Science Letters, 168, 7-14, [3] Trua et al., (2003), Terra Nova 15, 433-440 